\title{
О ВРЕМЕНИ ОБРАЗОВАНИЯ ФУЛЬСКОЙ ЕПАРХИИ В КРЫМУ
}

\author{
Ю. М. Могаричев
}

Могаричов Ю. М. Про час заснування Фульської єпархії у Криму. Автор розглядає проблему часу заснування Фульської єпархії на території Кримського півострова. Він аргументує думку, що вона була створена у 70-90-ті роки IX століття, після того, як Візантії вдалося повністю витіснити хозарів з території Кримського півострова.

Ключові слова: Крим; Фульська єпархія; Візантія; хозари.

Могаричев Ю. М. О времени образования Фульской епархии в Крыму. Автор рассматривает проблему времени образования на территории Крымского полуострова Фульской епархии. Он аргументирует мнение, что она была образована в 70-90-х гг. IX в., после того, как Византии удалось полностью вытеснить хазар с территории Крымского полуострова.

Ключевые слова: Крым; Фульская епархия; Византия; хазары.

Mogarychev Yu. M. On the Formation Time of the Foulian Eparchy in Crimea. The author examines the problem of formation of the Foulian eparchy on Crimean peninsula. He argues that it was created in 70-90 of $9^{\text {th }}$ century after Byzantine had superseded Khazars from Crimea.

Keywords: Crimea; Foulian eparchy; Byzantine; Khazars.

Средневековые источники, по крайней мере начиная со второй половины VIII в., фиксируют на территории Крымского полуострова Фулы (Фуллы) - населенный пункт, христианскую епархию и, возможно, некую область ${ }^{1}$. Впервые в источниках достоверно $\Phi_{\text {Флы }}{ }^{2}$ отмечены в Житии Иоанна Готского ${ }^{3}$. Древнейшая версия этого агиографического произведения, скорее всего, была составлена в 806-811 гг. В период патриаршества Мефодия (843-847 гг.) оно было переработано в новой, уже известной нам редакции ${ }^{4}$. Среди чудес, совершенных святым, присутствует сюжет о том, что когда «преподобный сидел в темнице Фул» (после подавления антихазарского выступления в Готии, случившегося между концом 784 и 786 г. $^{5}$ ), он посредством крещения исцелил сына «владетеля» этого населенного пункта: «Когда преподобный сидел в темнице Фул, владетель этих самых Фул, придя, бросил к его ногам свое дитя, покрытое от головы до ног ранами, так что казалось, не было на нем человеческого облика. Когда же (Иоанн), осенив его крестным знамением и окрестив, принял в свои объятья, то дитя тотчас очистилось от ран» ${ }^{6}$.

Затем Фулы, вернее «народ фульский», фигурируют в Пространном Житии Константина Философа (Гл. ХІІ), составленном, скорее всего, между 869 и началом 880-х гг. ${ }^{7}$, в сюжете о «хазарской миссии» Константина (860-861гг.). Святой «уговорил» этот, уже христианский, народ ${ }^{8}$, отказаться от языческого обычая, а именно, поклонения большому дубу, сросшемуся с черешней: «Был же в народе фульском большой дуб, сросшийся с черешней, и под ним приносили жертвы, называя его Александр, - и женскому полу не позволяли ни подходить к нему, ни (приносить) ему жертвы. И когда услышал о том Философ, не пожалев трудов, направился к ним. И, став среди них, сказал: «Эллины пошли на вечные муки, поклоняясь [как богу] небу и земле, столь большим и добрым творениям. Так и вы, кто столь убогому созданию, дереву, приготовленному для огня, поклоняетесь, как избегнуть можете вечного огня?». Отвечали они: «Не теперь мы стали так делать, но (обычай этот) от отцов приняли, и благодаря ему исполняются все просьбы наши, а больше всего идут частые дожди. И как мы то совершим, что не дерзнул никто из нас совершить? Ведь если; кто и дерзнет сделать это, тогда же и смерть узрит, а дождя уж не увидит до (самой своей) кончины». Отвечал же им Философ: «Бог о вас говорит в Книгах, как же вы Его отвергаете? Ведь Исайя от лица Господня вопиет, говоря: «Иду я собрать все племена и народы, и придут, и увидят славу мою, и положу на них знамение, и пошлю из спасенных от них к народам: в Тарсис и Фулу, и Луд, и Мосох; и Фовел, и в Элладу, и на острова дальние, где не слышали моего имени, и возвестят славу мою народам». И 
снова говорит Господь вседержитель: «Вот пошлю я рыболовов и охотников многих на холмах и скалах каменных изловить вас». Познайте, братья, Бога, сотворившего вас. Вот евангелие Нового завета божьего, в котором были вы крещены». И так, сладкими словами уговорив, приказал им срубить дерево и сжечь его. Поклонился же их старейшина и подошел поцеловать Евангелие, а за ним и все (остальные). И, взяв белые свечи у Философа, с пением пошли к дереву, и, взяв топор, ударил Философ тридцать три раза, и приказал всем срубить с корнем и сжечь его. В ту же ночь пошел дождь от Бога. И с радостью великою похвалили Бога, и Бог сильно возрадовался этому» ${ }^{9}$.

Насколько исторически реальным было данное событие - вопрос научных дискуссий. Как представляется, данный сюжет несет в себе отчетливые следы агиографического штампа. Отметим, что Глава XII Жития Константина в целом составлена исключительно как изложение чудес: сначала чудо с превращением соленой воды в пресную, которое является начальным ${ }^{10}$, затем чудо предсказания скорой смерти херсонскому архиепископу и, наконец, чудо возвращения на путь истинный фульского народа. Как подтверждение данной гипотезы, отметим проводимую автором Жития аллюзию, выразившуюся в игре слов, между «народом Фулу» из цитируемой Константином Философом речи пророка Исайи (еврейский текст Библии) (Исайа. 66. 18-19) 11 и крымским «народом фульским». Однако, сказанное выше не отрицает существование на Крымском полуострове в середине IX в. местности, именуемой Фулы.

B Not. III (по Ж. Даррузе), или Нотиции Де Боора упомянут епископ хотциров ((о) хоциров), резиденция которого находилась рядом с Фулами и Харасиу $(я)^{12}$. Согласно этому документу, в Готскую митрополию с центром в Доросе входили семь епископий, охватывавших районы Нижнего Поволжья, Северо-Западного Прикаспия, пространства между Каспийским и Азовским морями, Таманский полуостров, большую часть Крыма ${ }^{13}$. Первый издатель документа, К. Де Боор, склонен был считать, что нотиция не являлась официальным документом и носила компилятивный характер. Он датировал ее временем около 787 г., а крымскую часть - периодом правления Юстиниана $\mathrm{I}^{14}$. Ю. А. Кулаковский определял время составления документа - второй половиной VIII в. ${ }^{15}$. А. Л. Бертье-Делагард относил «таврическую» часть ко времени не ранее XI в. ${ }^{16}$. А. А. Васильев считал нотицию поздней подделкой ${ }^{17}$. М. И. Артамонов датировал источник периодом между 80-ми гг. VIII в. (в Житии Иоанна Готского о митрополии ничего не сказано) и началом IX в. (в нотициях этого времени митрополия уже не упоминается) ${ }^{18}$. В. Мошин ${ }^{19}$ и $Г$. Вернадский ${ }^{20}$ пришли к заключению, что документ не имел официального статуса, а представлял собой нереализованный проект по церковной организации Хазарии. Причем, по мнению Г. Вернадского, появление проекта явилось следствием «хазарской» миссии Константина Философа 860-861 гг. Д. Оболенский относил рассматриваемый список епархий к промежутку между 733 и 746 гг. и полагал, что «не существует убедительных причин, почему византийские планы по созданию миссионерской Церкви на всем пространстве хазарских владений должны были остаться на бумаге» ${ }^{21}$. В пользу хронологии (без дополнительных аргументов) «готской части» Not. III серединой VIII в. склоняется и T. Нунан 22. В итоге Ж. Даррузе, проведя обстоятельный анализ, датировал нотицию периодом ближе к 70-м гг. IX в. ${ }^{23}$. Этой точки зрения придерживаются и ряд современных исследователей ${ }^{24}$. К. Цукерман, согласившись с «рабочим» характером источника, относил его составление ко времени около $806 \Gamma^{25}$. В целом, в отношении Not. III в современной историографии так же имеются мнения от предположения как об источнике второй половины VI в. (если не всего документа, то его отдельных частей $)^{26}$ и документе середины - конца VIII в. ${ }^{27}$, до представления как о поздней компиляции ${ }^{28}$.

Таким образом, Not. III, по наиболее обоснованной аргументации, была составлена в IX в., возможно, в его второй половине. Она представляла собой проект, или его черновой набросок, в итоге так и не реализованный, охвата Хазарии системой христианских епархий 29.

В начале Х в. (по мнению К. Цукермана не ранее лета $920 г_{.}^{30}$ ) Not. VII (по Ж. Даррузе) фиксирует функционирование Фульской епархии, которая встречается и в последующих росписях церковных административно-территориальных единиц вплоть до середины XII в. ${ }^{31}$. Затем Фульская епархия была объединена с Сугдейской и возведена в ранг митрополии. На Константинопольском соборе 1158 г., проходившем в период патриаршества Луки Хрисоверга (1156-1169 гг.), присутствовал архиепископ уже Сугдо-Фульской епар- 
хии $^{32}$. Согласно припискам на полях Сугдейского синаксаря, «(за 9 или 10 января) в этот самый день упокоился архиепископ сугдофуллов Феодор, переименованный в Феодосия монаха, 6782-го года (от сотворения мира)» $(1273 \text { г.) })^{33}$. А уже в 1282 г. скончался первый сугдофульский митрополит Феодор: «(за 5 февраля) упокоился раб божий Феодор, митрополит сугдофуллов, тот, который (был возвышен) из архиепископов, 6790-го (да от сотворения мира)» ${ }^{34}$. B Not. 20 (XIV в.) поясняется: «Сугдея и Фуллы были архиепископиями, а будучи соединены, стали одной митрополией» ${ }^{35}$.

Приходится констатировать, что все предпринятые в историографии попытки «материализовать» Фулы успехов не имели. К сожалению, источники не сохранили никаких более или менее точных указаний, где Фулы должны были находиться. Поэтому вся аргументация исследователей, пытавшихся решить проблему локализации, строится, как правило, на более или менее удачных логических схемах этих же авторов. Сложность ситуации заключается еще и в том, что в Крыму трудно «найти место» для Фульской епархии. В Южной и Юго-Западной части полуострова находились Херсонская и Готская епархии, а в Юго-Восточной и Восточной - Боспорская и Сугдейская. При этом нет оснований помещать Фульскую епархию за пределы Крыма, на Таманском полуострове, как это делал еще Н. М. Мурзакевич ${ }^{36}$. Нотиции в это время фиксируют там церковно-административную единицу с центром в Таматархе ${ }^{37}$.

«Виртуальность» Фул заключается и в отсутствии каких-либо иных, кроме перечисленных, источников. Так, особенно в последние два десятилетия, в научный оборот введены моливдовулы ряда херсонских, боспорских, сугдейских и готских церковных иерархов $^{38}$. При этом, несмотря на выявление херсонского и судакского архивов печатей, моливдовулов фульских иерархов не обнаружено. Различные источники сохранили имена ряда светских правителей и иных должностных лиц Херсона, Боспора, Сугдеи, Готии. Более того, мы имеем определенное представление об эволюции там административнотерриториального устройства. Но нет ни одного свидетельства, позволяющего пролить свет на то, какому должностному лицу подчинялась территория Фульской епархии (кроме анонимного правителя Фул малоинформативного в этом плане Жития Иоанна Готского). То же касается и эпиграфических источников.

Оставляя за рамками работы проблему места нахождения Фул, отметим, что в настоящее время в историографии насчитывается более 20 вариантов локализации этого «неуловимого» места. Согласно наиболее аргументированным гипотезам, Фулы (на каком поселении их бы не помещали авторы) находились или в Юго-Западной, или в Юго-Восточной части полуострова. Однако, в пользу «восточной» гипотезы имеется важный аргумент. Как уже отмечалось, с XII в. Фульская епархия была объединена с Сугдейской, и эта новая церковно-административная единица фиксируется вплоть до 1410 г. Более того, во второй половине XV в. в Каффе образуется униатская Фульская епархия, а с начала XVII в. создается Каффо-Фульская епархия ${ }^{39}$. Сложно предположить, чтобы соединяемые церковно-административные единицы не располагались по соседству. В случае нахождения Фульской епархии в юго-западной части Крыма ее логично было присоединить к близлежащей Готии, а не к отдаленной Сугдее. Однако, «восточной гипотезе» противоречит археологическая ситуация в Юго-Восточном Крыму. Согласно упомянутым источникам, функционирование Фул и одноименной епархии должны отражать поселения, на которых присутствуют археологические слои как минимумом второй половины VIII - середины XII вв. При этом таких памятников должно быть несколько. Однако отвечающая этим требованиям стратиграфия в Восточном Крыму выявлена только в городах Боспоре и Сугдее. Иные поселения и могильники X (по крайней мере, начиная со второй четверти столетия) - XI в. в Юго-Восточном Крыму отсутствуют ${ }^{40}$.

Проблему времени образования Фульской епархии наиболее обстоятельно рассмотрел К. Цукерман. Он аргументировал гипотезу, что она была основана на территории Крымской Хазарии поздним летом - ранней осенью 920 г. Процесс ее формирования нашел отражение в письмах Константинопольского патриарха Николая Мистика (№ 68 и № 106). A Not. VII уже зафиксировала факт существования этой церковно-административной единицы. При этом крымские хазары упоминаются уже в Not. III под именем хотциров ${ }^{41}$.

И. А. Завадская попыталась «материализовать» версию К. Цукермана: кафедральный собор Фул - это церковный комплекс в центральной части поселения Тепсень (третий 
строительный период). Тамошняя базилика, возведенная при участии мастеров из Преслава, была, несомненно, «первой кафедральной церковью Фульской епархии» ${ }^{42}$.

В предыдущих работах мы попытались показать, что предположение об отождествлении хазар с хотцирами не является достаточно аргументированным ${ }^{43}$. Николай Мистик под термином «Хазария» мог понимать только одно государственное образование - Хазарский каганат. «Крымская Хазария» начала X в., скорее всего, - не более, чем историографический миф ${ }^{44}$. Анализ археологического материала и последовательности строительных периодов тепсеньской базилики показывает ошибочность основных выводов И. А. Завадской ${ }^{45}$.

Как уже отмечалось, впервые Фульская епархия появилась в Not. VII. Однако дает ли это основание датировать ее только хронологическим периодом, близким ко времени составления указанного списка епархий? Напомним, что в этом же источнике первый раз в официальных списках фиксируются также Готская и Сугдейская епархии ${ }^{46}$. Однако Готская епархия была основана явно ранее начала X в., скорее всего, в конце VIII - начале IX в. ${ }^{47}$. В работе VII Вселенского собора в Никее (787 г.) принимал участие и Сугдейский епископ ${ }^{48}$. Возможные объяснения изложенной ситуации могут быть следующие. Или в Not. VII были впервые официально зафиксированы и структурированы изменения в церковно-административной системе Византии, которые произошли ранее ${ }^{49}$, либо Готская и Сугдейская епископии до начала $\mathrm{X}$ в. административно являлись подразделениями соответственно Херсонской и Боспорской епархий и поэтому не попали в перечни самостоятельных церковно-административных подразделений империи. В любом случае попытка «привязать» образование Фульской епархии исключительно к периоду составления Not. VII не выглядит убедительной.

Когда же могла быть основана епархия с центром в Фулах? Если принять во внимание информацию Жития Иоанна Готского, в последней четверти VIII - первой половине IX в., времени сюжета и составления источника, этой церковно-административной единицы еще не существовало. Агиограф вряд ли бы вставил в свое произведение, в целом в традиционный для житий сюжет об исцелении Иоанном посредством крещения сына местного правителя (судя по контексту источника, вероятно, язычника), будь в Фульской области свой епископ и, соответственно, достаточно много христиан.

Не было, скорее всего, епархии и на момент хазарской миссии Константина Философа. Мы отмечали, что эпизод «возвращения на путь истинный фульского народа», возможно, несет следы агиографического штампа. Но при этом Житие однозначно свидетельствует, что «фульский народ» хоть и подвержен пережиткам язычества, но, несомненно, уже принадлежит к числу христианских ${ }^{50}$. Маловероятно, что при наличии там отдельной епархии и своего настоятеля агиограф таким образом построил бы сюжет. Ведь выходит, что Константин действует в обход и за спиной Фульского епископа и, соответственно, нарушает существующие церковные правила.

Можно с определенной уверенностью утверждать, что Фульская епархия не функционировала и на момент составления Not. III (даже учитывая ранее изложенные выводы в отношении этой росписи епархий). Несомненно, автор руководствовался некими реалиями. Вряд ли можно сомневаться, что тогда в Крыму уже действовали отмеченные в источнике Херсонская, Боспорская, Сугдейская и Готская епархии. При этом, на базе Готской предлагалось организовать «хазарскую митрополию». Фулы же, в данном случае, упоминаются не как епархиальный центр, а всего лишь как ориентир для «привязки» места нахождения епископа хотциров. Отметим, что даже учитывая проблематичность датировки Not. III, маловероятно, чтобы она была составлена намного позже «хазарской миссии» Константина Философа.

Таким образом, скорее всего, Фульская епархия была основана между 861 г. (как вариант -60 -ми гг. IX в.) и началом X в. (Not. VII еe уже фиксирует). Если принять датировку Not. VII, предложенную К. Цукерманом, то это 920 г.

Позволим высказать предположение о возможной связи создания Фульской епархии и окончательным уходом хазар из Крыма. Уже А. Л. Якобсон писал о фактической утрате хазарами власти в Крыму к середине IX в. По его мнению, хазарские дружины в это время могли оставаться разве что на Боспоре ${ }^{51}$. К. Цукерман показал, что ко времени путешествия Константина Философа у хазар, вытесненных венграми, на полуострове уже не оставалось 
опорных пунктов ${ }^{52}$. В попытке вернуть крымские владения или получить дань они могли совершать походы на полуостров только из-за его пределов ${ }^{53}$. А. И. Айбабин считает, что хазар изгнали из Крыма «спустя некоторое время» после 861 г., а именно, ближе к 873 г. Основанием для такой хронологии послужил как анализ археологического материала, так и письмо Константинопольского патриарха Фотия архиепископу Боспора с поддержкой желания последнего крестить проживавших там иудеев ${ }^{54}$ : «Если же ты, пленив тамошних евреев на послушание Христу, обратишь от тени буквы к благодати, как написал, то получаю и с избытком получаю прекрасные плоды добрых надежд, которые постоянно к тебе питал» ${ }^{55}$.

Конечно, можно по-разному трактовать письмо Фотия. Нам представляется, что его следует рассматривать в контексте византийской истории того времени. Известно, что в период правления Македонской династии при Василии I (867-886 гг.), после ряда попыток убедить византийских евреев принять христианство, был издан декрет об обязательном и насильственном их крещении ${ }^{56}$. К. Цукерман рассматривает это событие как реакцию византийских властей на иудаизацию Хазарии ${ }^{57}$. Мы не знаем, были ли крещены местные евреи и что произошло с непокорными. Но, вероятнее всего, желание Антония крестить иудеев - в большей степени верноподданный «рапорт с мест» о поддержке политики императора ${ }^{58}$. Но даже это не исключает факта прекращения хазарского господства в Крыму к началу 70-х гг. IX в. ${ }^{59}$. В. Е. Науменко сначала датировал окончательный выход Таврики из сферы влияния Хазарии временем «к 70-80-м гг. IX в.» ${ }^{60}$, а затем ограничил 80-ми гг. IX в. ${ }^{61}$.

Вполне возможно, что в 70-90-х гг. IX в., после того как Византии удалось полностью вытеснить хазар с территории Крымского полуострова, здесь была проведена очередная реорганизация церковно-административной системы и, в силу ряда до конца не совсем понятных обстоятельств, была создана Фульская епархия. Этот факт и был зафиксирован Not. VII в начале X в.

${ }^{1}$ Последние историографические обзоры «фульской проблемы» см: Кропоткин В. В. Из истории средневекового Крыма (Чуфут-Кале и локализация города Фулл) // Советская археология. 1958. Т. 28. С. 199-203; Майко В. В. О локализации Фулл и Фулльской епархии в раннесредневековой Таврике // Православные древности Таврики. К., 2002. С. 133-145; Майко В. В. Средневековое городище на плато Тепсень в Юго-Восточном Крыму. К., 2004. С. 10-16; Байер Х.-Ф. История Крымских готов как интерпретация Сказания Матфея о городе Феодоро. Екатеринбург, 2001. С. 62-68: Cорочан С. Б. «Зачарованный клад» Еще раз о локализации Фул (Фулл) // Античная древность и средние века. Екатеринбург, 2002. Вып. 33. С. 71-79; Сорочан С. Б. Византийский Херсон. Ч. 1-2. Харьков, 2005. С. 516-523, сноска 88; Сорочан С. Б. К проблеме локализации Фул и «народа Фульского» // Государственная территория как фактор политогенеза. Восточная Европа в древности и средневековье. М., 2015. Вып. XXVII. С. 238-243; Могаричев Ю. М., Сазанов А. В., Шапошников А. К. Житие Иоанна Готского в контексте истории Крыма «хазарского периода». Симферополь, 2006. С. 252-255; Завадская И. А. Периодизация церковного строительства на городище Тепсень (о кафедральном храме Фульской епархии) // Материалы по археологии, истории и этнографии Таврии. СимферопольКерчь, 2014. Вып. ХІХ. С. 212; Могаричев Ю. М., Майко В. В. Фулы и Крымская Хазария: еще раз о локализации Фульской епархии // Laurea I. Античный мир и Средние века: Чтения памяти профессора Владимира Ивановича Кадеева. Харьков, 2015. С. 130-134; Могаричев Ю. М., Майко В. В. Тепсеньская базилика и проблема локализации Фул // Хазарский Альманах. М., 2015. Т. 13. С. 130-144.

2 Мы следуем раннесредневековой традиции написания Фул с одной буквой «лямбда» (Сорочан С. Б. Византийский Херсон. С. 516).

3 По мнению ряда исследователей, начиная с М. Тунманна (Тунманн Крымское ханство. Симферополь, 1991. С. 33), первый раз Фулы все же упоминаются Менандром Протектором в 576 г. (см.: Байер $X .-\Phi$. История Крымских готов как интерпретация Сказания Матфея о городе Феодоро. C. 64). Однако, фрагмент, якобы упоминающий эту местность, дошел к нам в испорченном состоянии. Кроме того, еще В. Томашек (Tomaschek W. Die Gothen in Taurien. Wien, 1881. Р. 71), а вслед за ним и Ю. А. Кулаковский достаточно аргументированно полагали, что в источнике речь идет не о местности с таким названием, а о филах - племенах (Кулаковский Ю. А. Где находились Фуллы? // Журнал Министерства народного просвещения. 1898. № 2. С. 194). С такой точкой зрения согласны и большинство современных исследователей (подробнее см. Бельй $A$. B. Вопрос о локализации Фулл в связи с неясным свидетельством Менандра // Проблемы археологии древнего и средневекового Крыма. Симферополь, 1995. С. 99-94).

${ }^{4}$ См. подр.: Могаричев Ю. М., Сазанов А. В., Шапошников А. К. Житие Иоанна Готского в контексте истории Крыма «хазарского периода». С. 16-26. 
${ }^{5}$ Гериен А. Г., Могаричев Ю. М. О возникновении Готской епархии в Крыму // Материалы по археологии, истории и этнографии Таврии. Симферополь, 1991. Вып. 2. С. 115; Могаричев Ю. М., Сазанов А. В., Шапошников А. К. Житие Иоанна Готского в контексте истории Крыма «хазарского периода». С. 109-199.

${ }^{6}$ Могаричев Ю. М., Сазанов А. В., Шапошников А. К. Житие Иоанна Готского в контексте истории Крыма «хазарского периода». С. 14.

${ }^{7}$ Флоря Б. Н. Сказания о начале славянской письменности. М., 1981. С. 10; Байер Х.-Ф. История крымских готов как интерпретация Сказания Матфея о городе Феодоро. С. 75; Цукерман К. Венгры в стране Леведии: новая держава на границах Византии и Хазарии // Материалы по археологии, истории и этнографии Таврии. Симферополь, 1998. Вып. VI. С. 677; Цукерман К. О происхождении двоевластия у хазар и обстоятельствах их обращения в иудаизм. Материалы по археологии, истории и этнографии Таврии. Симферополь, 2002. Вып. IX. С. 525-526; Zuckerman C. On the date of the khazars' conversion to Judaism and the chronology of the kings of the Rus Oleg and Igor // Revue des Etudes Byzantines. Paris, 1995. T. 53. P. 243; Colden P. The conversion of the Khazars to Judaism // The World of the Khazars. New Perspectives Selected Papers from the Jerusalem 1999 International Khazar Colloquium hosted by the Ben Zvi Institute. Handbook of Oriental Studies. LeidenBoston, 2007. P. 140.

${ }^{8}$ Сорочан С. Б. «Народ фульский»: язычники или христиане? // Язычество и монотеизм в процессах политогенеза. Восточная Европа в древности и средневековье. М., 2014. Вып. XXVI. С. $246-250$.

${ }^{9}$ Флоря Б. Н. Сказания о начале славянской письменности. С. 85-86.

${ }^{10}$ Когда же дошли до пустых и безводных мест, не могли переносить жажды. Найдя же в солончаке воду, не могли ее пить, ибо была она как желчь. И когда разошлись они все искать воду, сказал брату своему Мефодию: «Не могу больше терпеть от жажды, зачерпни же воды этой. Тот, кто раньше для израильтян горькую воду сделал сладкой, Тот и нам принесет утешение». Зачерпнули же, и оказалась она сладкой, как мед, и холодной, и пили, прославляя Бога, что делает такое для рабов своих (Флоря Б. Н. Сказания о начале славянской письменности. С. 85).

${ }^{11}$ См. подробнее: Флоря Б. Н. Сказания о начале славянской письменности. С. 123. Прим. 5.

${ }^{12}$ Boor K. de. Analitiken (I-III). Nachträge zu den Notitiae Episcopatuum. // Zeitschrift für Kirchengeschichte Theologie. Bd., 1891. V. XII. S. 533; Darrouzes J. Notitiae episcopatuum eclessiae Constantinopolitanei. Paris, 1981. P. 245.

${ }^{13}$ Darrouzes $J$. Notitiae episcopatuum ecclesiae Constantinopolitanae. P. 611-618.

${ }^{14}$ Boor K. de. Analitiken (I-III). Nachträge zu den Notitiae Episcopatuum. S. 303-322, 519-534.

${ }^{15}$ Кулаковский Ю. А. К истории Готской епархии (в Крыму) VIII в. С. 175-193.

16 Бертье-Делагард А. Л. Исследование некоторых недоуменных вопросов средневековья в Тавриде. // Бертье-Делагард А. Л. Избранные труды по истории христианства в Крыму. Симферополь, 2011. T. II. C. 43-49.

17 Васильев A. A. Готы в Крыму. Ч. 2. // Известия Государственной академии истории и материальной культуры. М.-Л., 1927. Вып. 5. С. 210-216.

${ }_{18}^{18}$ Артамонов М. И. История хазар. СПб., 2001. С. 352-358.

19 Мошин В. Готская епархия в Хазарии в VIII в. // Труды IV съезда русских академических организаций за границей. Белград, 1929. С. 249-256.

${ }^{20}$ Vernadsky G. Byzantium and Southern Russian. I. The Eparchy of Gothia // Byzantion. 1940-1941. V. 15. P. 67-76.

${ }^{21}$ Оболенский Д. Византийское содружество наций. М., 1998. С. 186.

${ }^{22}$ Noonan T. Byzantium and Khazars: a special relationship? // Byzantine diplomacy. Variorum, 1992. P. 114.

${ }^{23}$ Darrouzes $J$. Notitiae episcopatuum ecclesiae Constantinopolitanae. P. 31-33

${ }^{24}$ Науменко B. E. Церковная география Таврики в VII - IX вв. по данным Notittiae episcopatuum // Крымский архив. Симферополь, 1999. № 5. С. 12-18; Науменко В. Е. К вопросу о церковноадминистративном устройстве Таврики в VIII-IX вв. (по данным Notittiae episcopatuum) // Античная древность и средние века. Екатеринбург, 2003. Вып. 34. С. 138-140; Иванов C. А. Миссия восточнохристианской церкви к славянам и кочевникам: эволюция методов // Славяне и их соседи. М., 2001. Вып. 10. С. 30-33; Могаричев Ю. М., Сазанов А. В., Шапошников А. К. Житие Иоанна Готского в контексте истории Крыма «хазарского периода. С. 178-179.

${ }^{25}$ Zuckerman C. Byzantium's Pontic Policy in the Notitiae episcopatuum // La Crimee entre Byzance et le Khaganat Khazar. Paris, 2006. P. 214; Цукерман К. Политика Византии в Северном Причерноморье по данням Notitiae episcopatuum // Материалы по археологии, истории и этнографии Таврии. Симферополь, 2010. Вып. XVI. С. 401-414.

${ }^{26}$ Атанасов Г. Бележки и допълнения към църковната организация в Мизия и Скития през IV-VII в. (Notes and Codicils to the Ecclesiastical Structure of Scytia and Moesia Secunda during 4th6th Century AD) // Сборник в чест на Ал. Минчев. Acta musei varnaensis. Варна, 2008. № VIII-1. C. 307-309. 
${ }^{27}$ Cм. напр.: Prigent $V$. Les eveches bizantins de la Calabre septentrionale au VIIIe siècle // Melanges de L^Ecole Francaise de Rome. Moyen Age. 2002. V. 114. P. 931-953; Коматина П. Црквена политика Византије од крајя иконоборства до смрти цара Василија. Београд, 2014. С. 304-305.

${ }_{28}$ Lamberz E. Die Bischofslisten dez VII Okumenischen Konzils (Nicaenum II). Munchen, 2004. S. 24-25. Мы не претендуем на исчерпывающий историографический анализ проблемы. Последние историографические обзоры: Науменко $B . E$. К вопросу о церковно-административном устройстве Таврики в VIII-IX вв. С. 133-142; Могаричев Ю. М., Сазанов А. В., Шапошников А. К. Житие Иоанна Готского в контексте истории Крыма «хазарского периода». С. 178; Цукерман К. Политика Византии в Северном Причерноморье по данням Notitiae episcopatuum. C. 401-402.

${ }^{29}$ Иванов C. A. Миссия восточнохристианской церкви к славянам и кочевникам: эволюция методов. C. 30-31; Науменко B. E. Церковная география Таврики в VII-IX вв. по данным Notittiae episcopatuum. C. 12-18; Науменко B. E. К вопросу о церковно-административном устройстве Таврики в VIII-IX вв. C. 136-140.

${ }^{30}$ Цукерман К. Политика Византии в Северном Причерноморье по данным Notitiae episcopatuum. C. $419-427$.

${ }_{31}$ Кропоткин В. В. Из истории средневекового Крыма (Чуфут-Кале и локализация города Фулл). C. 203; Darrouzes J. Notitiae episcopatuum eclessiae Constantinopolitanei. P. 273-274, 294, 346, 352, 377, 385,389 .

${ }_{32}$ Васильевский В. Г. Житие св. Стефана Сурожского // Васильевский В. Г. Труды. Пд, 1915. Т. 3. C. CLXV. По мнению этого автора, Сугдейская и Фульская епархии к концу XII в. на некоторое время вновь были объединены. Однако хронология источников, на которые ссылается этот исследователь (C. CLXV), требует уточнения.

${ }^{33}$ Могаричев Ю. М., Сазанов А. В., Степанова Е. В, Шапошников А. К. Житие Стефана Сурожского в контексте истории Крыма иконоборческого времени. Симферополь, 2008. С. 284. № 43.

34 Могаричев Ю. М., Сазанов А. В., Степанова Е. В, Шапошников А. К. Житие Стефана Сурожского в контексте истории Крыма иконоборческого времени. С. 6, 285. № 57.

${ }^{35}$ Байер $X .-\Phi$. История Крымских готов как интерпретация Сказания Матфея о городе Феодоро. C. 67.

${ }^{36}$ Бертье-Делагард А. Л. Исследование некоторых недоуменных вопросов средневековья в Тавриде. С. 66.

${ }^{37}$ Кропоткин В. В. Из истории средневекового Крыма (Чуфут-Кале и локализация города Фулл). С. 203; Чхаидзе В. Н. Тамартаха. Раннесредневековый город на Таманском полуострове. М., 2008. C. $292-294$.

${ }^{38}$ См. напр. Алексеенко Н. А. Печати церковных иерархов из Херсона // Nomos. T. 28/29. Krakow, 1999/2000. С. 95-103; Алексеенко Н. А. Моливдовулы боспорских епископов из Херсона // Проблемы религий стран Черноморско-Средиземноморского региона. Севастополь, 2001. С. 131138; Алексеенко H. А. «Херсонский архив печатей»: миф или реальность // Херсонесский сборник. Севастополь, 2006. Вып. XV. С. 8; Соколова И. В. Монеты и печати византийского Херсона. Л., 1983. С. 166; Соколова И. В. Византийские печати VI - первой половины IX в. из Херсонеса // Византийский временник. М., 1991. Т. 52. С. 209; Могаричев Ю. М., Сазанов А. В., Степанова Е. В., Шапошников $A$. K. Житие Стефана Сурожского в контексте истории Крыма иконоборческого времени. С. 184-185; Чхаидзе В. Н. Византийские печати из Тамани. М., 2015. С. 93-94.

${ }^{39}$ Кропоткин В. В. Из истории средневекового Крыма (Чуфут-Кале и локализация города Фулл).

40 Зинько В. Н. Восточный Крым в эпоху Хазарского каганата // Хазары: миф и история. МоскваИерусалим, 2010. С. 239; Майко В. В. Средневековое городище на плато Тепсень в Юго-Восточном Крыму. С. 41-45; Майко B. B. Византийско-русские отношения в юго-восточном Крыму в XI в. // Проблемы истории, филологии, культуры. Вып. XVI/1. М.-Магнитогорск, 2006. С. 217; Пономарев Л. Ю. О населении Керченского полуострова во второй половине X-XIII вв. // Причерноморье, Крым, Русь в истории и культуре. Материалы II Судакской международной научной конференции. Киев-Судак, 2004. Ч. II. С. 164-169.

${ }^{41}$ Цукерман К. Политика Византии в Северном Причерноморье по данным Notitiae episcopatuum. C. 419-427.

42 Завадская И. А. Периодизация церковного строительства на городище Тепсень (о кафедральном храме Фульской епархии) // Материалы по археологии, истории и этнографии Таврии. Симферополь-Керчь, 2014. Вып. ХІХ. С. 211-239.

${ }^{43}$ Могаричев Ю. М., Майко В. В. Тепсеньская базилика и проблема локализации Фул. С. 141-143; Могаричев Ю. М., Майко В. В. Фулы и Крымская Хазария: еще раз о локализации Фульской епархии. C. $131-132$.

${ }^{44}$ Могаричев Ю. М. К вопросу о «Крымской Хазарии» в Х-ХІ вв. // Восточная Европа в древности и средневековье. Миграции, расселение, война как факторы политогенеза. XXIV Чтения памяти В. Т. Пашуто. М, 2012. С. 192-196; Могаричев Ю. М., Сазанов А. В. Крымская Хазария X-XII вв. 
Хазарский анклав в Крыму или историографический миф? (исторический контекст) // Хазарский Альманах. Киев-Харьков, 2012. Т. 10. С. 123-129.

${ }^{45}$ Могаричев Ю. М., Майко В. В. Тепсеньская базилика и проблема локализации Фул. С. 141-143; Могаричев Ю. М., Майко В. В. Фулы и Крымская Хазария: еще раз о локализации Фульской епархии. C. $131-132$.

${ }^{46}$ Науменко В. Е. Церковная география Таврики в VII-IX вв. по данным Notittiae episcopatuum. C. 19; Науменко B. E. К вопросу о церковно-административном устройстве Таврики в VIII-IX вв. C. $143-144$.

${ }^{47}$ См. подр.: Гериен А. Г., Могаричев Ю. М. О возникновении Готской епархии. С. 119-122; Гериен А. Г., Могаричев Ю. М. К вопросу о церковной истории Таврики в VIII в. // Античная древность и средние века. Екатеринбург, 1999. Вып. 30. С. 110-115; Могаричев Ю. М. Крым и Нижнедунайский регион: проблема локализации позднеантичных и раннесредневековых историкогеографических областей в российской, советской и украинской историографии // Преслав Сборник. Велико Търново, 2013. Т. 7. С. 345-352; Могаричев Ю. М., Сазанов А. В., Шапошников А. К. Житие Иоанна Готского в контексте истории Крыма «хазарского периода». С. 177-182.

${ }^{48}$ Mansi J. D. Sacrorum consiliorum nova et amplissima collection. V. 12. Graz., 1960. P. 994, 1096, 1154; V.13. P. 138, 366, 384; Могаричев Ю. М., Сазанов А. В., Степанова Е. В, Шапошников А. К. Житие Стефана Сурожского в контексте истории Крыма иконоборческого времени. С. 86-87. Вероятнее всего сугдейская епархия была основана в середине VIII в.

${ }^{49}$ Науменко B. E. Церковная география Таврики в VII-IX вв. по данным Notittiae episcopatuum. C. 19; Науменко В. E. К вопросу о церковно-административном устройстве Таврики в VIII-IX вв. C. $143-144$.

${ }^{50}$ Васильевский В. Г. Житие св. Стефана Сурожского. С. CLXV; Сорочан С. Б. «Народ фульский»: язычники или христиане? С. 246-250.

${ }_{51}$ Якобсон А. Л. Средневековый Крым. М.-Л., 1964. С. 55

${ }^{52}$ Цукерман К. Венгры в стране Леведии: новая держава на границах Византии и Хазарии ок. 836-889 г. С. 677; Цукерман К. О происхождении двоевластия у хазар и обстоятельствах их обращения в иудаизм. С. 527-530.

${ }^{53}$ Цукерман К. Венгры в стране Леведии: новая держава на границах Византии и Хазарии ок. $836-889$ г. С. $678-679$.

${ }_{54}$ Айбабин А. И. Этническая история ранневизантийского Крыма. Симферополь, 1999. С. 222.

${ }_{55}^{5}$ Байер $X .-Ф$. История Крымских готов как интерпретация Сказания Матфея о городе Феодоро. С. 118-119. В. Е. Науменко считает крещение боспорских евреев свершившимся фактом (Науменко B. E. К дискуссии о политико-административном статусе Боспора в X-XI вв. // Государственная территория как фактор политогенеза. Восточная Европа в древности и средневековье. М., 2015. Вып. XXVII. C. 212-213). Такой вывод выглядит странным, так как источник не дает для него абсолютно никаких оснований.

${ }^{56}$ Васильев А. А. История Византийской империи. Время до Крестовых походов. СПб., 1998. C. 437; Хазанов A. Евреи в раннесредневековой Византии // Вестник Еврейского университета в Москве. Москва-Иерусалим, 1994. № 1 (5). С. 25; Голден П. Хазарский иудаизм в свете письменных источников // История еврейского народа в России. Т. 1. Иерусалим-Москва, 2010. С. 139; Sharf A. Byzantine Jewry: from Justinian to the Fourth Crusade. New York, 1971. P. 82. C. 531.

${ }^{57}$ Цукерман К. О происхождении двоевластия у хазар и обстоятельствах их обращения в иудаизм.

${ }_{58}$ Могаричев Ю. М. К вопросу о «хазарском наследстве» (хазарские иудеи и проблема происхождения караимов и крымчаков) // Проблемы истории, филологии, культуры. М.-Магнитогорск, 2001. Вып. Х. С. 273.

${ }^{59}$ См. также: Могаричев Ю. М. К вопросу о «хазарском наследстве» (хазарские иудеи и проблема происхождения караимов и крымчаков). С. 273; Могаричев Ю. М., Сазанов А. В., Шапошников А. К. Житие Иоанна Готского в контексте истории Крыма «хазарского периода». С. 225-227.

${ }^{60}$ Науменко B. E. Место Боспора в системе византийско-хазарских отношений // Бахчисарайский историко-археологический сборник. Симферополь, 2001. Вып. 2. С. 353.

${ }^{61}$ Науменко В. Е. Таврика у контексті візантійско-хозарських відносин: політико-адміністративний аспект: автореф. дис. ... канд. іст. наук. К., 2004. С. 17. 